\title{
Splenic B-1a cells expressing CD138 spontaneously secrete large amounts of immunoglobulin in naïve mice
}

\section{Nichol E. Holodick ${ }^{1}{ }^{*}$, Teresa Vizconde ${ }^{1}$ and Thomas L. Rothstein ${ }^{1,2}$}

${ }^{1}$ Center for Oncology and Cell Biology, The Feinstein Institute for Medical Research, Manhasset, NY, USA

${ }^{2}$ Departments of Medicine and Molecular Medicine, Hofstra North Shore-LIJ School of Medicine, Manhasset, NY, USA

\author{
Edited by: \\ Catherine Pellat-Deceunynck, Centre \\ National de la Recherche Scientifique, \\ France

\section{Reviewed by:} \\ Claude-Agnes Reynaud, Institut \\ National de la Santé et de la \\ Recherche Médicale - INSERM, \\ France \\ Siegfried Weiss, Helmoholtz Centre \\ for Infection Research, Germany \\ ${ }^{*}$ Correspondence: \\ Nichol E. Holodick, The Feinstein \\ Institute for Medical Research, 350 \\ Community Drive, Manhasset, NY \\ 11030, USA \\ e-mail:nholodic@gmail.com
}

B-1a cells constitutively secrete natural antibody that provides immediate protection against microbial pathogens and functions homeostatically to speed removal of apoptotic cell debris. Although B-1a cells are especially prominent in the peritoneal and pleural cavities, some B-1a cells reside in the spleen. A small subset of splenic B-1a cells in naïve, unimmunized mice express CD138, a recognized plasma cell antigen, whereas the bulk of splenic B-1a cells are CD138 negative. Splenic B-1a cells in toto have been shown to generate much more antibody per cell than peritoneal B-1a cells; however, specific functional information regarding $\mathrm{CD} 138^{+}$splenic B-1a cells has been lacking. Here, we find a higher proportion of $\mathrm{CD}_{138^{+}}$splenic $\mathrm{B}-1$ a cells spontaneously secrete more $\mathrm{IgM}$ as compared to $\mathrm{CD} 138^{-}$B-1a cells. Moreover, IgM secreted by $\mathrm{CD}^{-138^{+}}$splenic B-1a cells is skewed with respect to $\mathrm{N}$-region addition, and some aspects of $\mathrm{V}_{H}$ and $\mathrm{J}_{H}$ utilization, as compared to $\mathrm{CD}_{138^{-}}$splenic B-1a cells and peritoneal B-1a cells. The small population of CD138+ splenic B-1a cells is likely responsible for a substantial portion of natural IgM and differs from IgM produced by other B-1a cell subsets.

Keywords: B lymphocytes, antibody, B-1 cells, IgM

\section{INTRODUCTION}

Murine B-1a cells represent a unique lymphocyte lineage distinguished by specific ontologic, phenotypic, and functional characteristics $(1,2)$. Although the human equivalent of mouse B-1a cells has been described recently $(3,4)$, most knowledge about Bla cells has been generated from studies in mice. It has been shown that B-1a cells spontaneously and constitutively generate "natural" immunoglobulin (Ig), which constitutes the vast majority of resting serum IgM and about half of resting IgA (5). The natural Ig produced by B-1a cells differs from Ig produced by B-2 cells. Bla cell Ig contains minimal $\mathrm{N}$-region addition and little somatic hypermutation (6-9). As a result, B- 1 a cell Ig tends to be "germlinelike"; that is, to accurately reflect germline sequences without the intervention of randomly added nucleotides or mutated residues. Because B-1a cell Ig reflects germline coding, the B-1a cell repertoire is to a large extent inherited. Therefore, those sequences that enhance an organism's survival to reproductive age are likely to be retained.

B-1a cell Ig is both polyreactive and autoreactive. Polyreactive natural Ig is always present and acts as an initial shield against many common infectious agents, particularly during the lag period that precedes the development of adaptive, high affinity antigen-specific antibody produced by germinal center B-2 cells $(10-15)$. Autoreactive natural Ig has been implicated in the disposition of irreversibly damaged cells and noxious molecular debris and in so doing maintains homeostasis and prevents untoward inflammation (16).

B-1a cells are preferentially located at serosal surfaces, most prominently in the peritoneal cavity. However, B-1a cells are also located in the spleen, and splenic B-1a cells differ from peritoneal
B-1a cells in a number of characteristics, including the intensity of Ig secretion (17-19). Through the unique property of self-renewal (20), mature B-1a cells can give rise to their own progeny in place, which suggests differentiation and migration in adult animals is minimal. Therefore, B-1a cells were considered for a time to represent static, Ig generating lymphocytes. However, recent reports suggest a richer life experience. Peritoneal B-1a cells may respond to specific and/or non-specific stimulation, migrate to the spleen, and may then return to the peritoneal cavity as memory B-1a cells (21-23). Further, a subset of splenic B-1a cells expresses CD138 (24) suggesting that appropriately stimulated B-1a cells may take a different path and differentiate in a plasma cell direction. $\mathrm{CD} 138^{+}$ B-1a cells differ from $\mathrm{CD} 138^{+}$plasma cells in retaining B-1aspecific surface antigen expression. Identification of splenic B-1a cells that express CD138 raises the question of whether $\mathrm{CD} 138^{+}$ B-1a cells differ from CD138- B-1a cells, or whether these splenic B-1a cell populations behave similarly, especially with respect to the amount of Ig secretion.

\section{MATERIALS AND METHODS}

MICE

Male BALB/c-ByJ mice of 6-8 weeks age were obtained from the Jackson Laboratory. Mice were cared for and handled in accordance with National Institutes of Health and institutional guidelines.

\section{CELL PURIFICATION AND FLOW CYTOMETRY}

Splenocytes were obtained from 8 to 14-week-old BALB/cByJ male mice and stained with fluorescence-labeled antibodies to $\mathrm{B} 220, \mathrm{CD} 5, \mathrm{CD} 23$, and $\mathrm{CD} 138$. Splenic B cell populations 
were sort-purified (BD Biosciences Influx) as follows: splenic B-2 cells, B220 hi ${ }^{-} D 5^{-} \mathrm{CD} 23^{\text {hi }} \mathrm{CD} 138^{-}$; splenic $\mathrm{CD} 138^{+}$B-1a cells, B220 ${ }^{\text {lo }} \mathrm{CD}^{10} \mathrm{CD}^{\mathrm{lo}} 3^{-} \mathrm{CD} 138^{+}$; splenic $\mathrm{CD} 138^{-}$B-1a cells, $\mathrm{B} 220^{\mathrm{lo}} \mathrm{CD} 5^{\mathrm{lo}} \mathrm{CD} 23^{-} \mathrm{CD} 138^{-}$. Post-sort analysis of the splenic B$1 \mathrm{a}$ and B-2 cell populations showed each to be $\geq 98 \%$ pure. The following rat anti-mouse antibodies were obtained from $\mathrm{BD}$ Biosciences: FITC-conjugated B220 (clone RA3-6B2), PE-Cy5conjugated CD5 (clone 53-7.3), PE-conjugated CD138 (clone 281-2). The anti-mouse Pacific Blue-conjugated CD23 antibody (clone B3B4) was obtained from BioLegend.

\section{ELISPOT ASSAY}

ELISPOT assay was carried out as previously described (25). In brief, sort-purified, naive $\mathrm{B}$ cells were distributed onto MultiScreen*-IP Plates (Millipore) pre-coated with goat antimouse $\operatorname{Ig}(\mathrm{H}+\mathrm{L})$ and then incubated in RPMI 1640 containing $10 \%$ heat-inactivated fetal bovine serum, $2 \mathrm{mM}$ L-glutamine, $50 \mu \mathrm{M} 2$-mercaptoethanol, $100 \mathrm{U} / \mathrm{ml}$ penicillin, and $100 \mu \mathrm{g} / \mathrm{ml}$ streptomycin for $4 \mathrm{~h}$ at $37^{\circ} \mathrm{C}$ and $5 \% \mathrm{CO}_{2}$. Plates were treated with alkaline phosphatase-conjugated goat anti-mouse IgM (Southern Biotechnology Associates) and developed with 5-bromo4-chloro-3-indolyl phosphate/p-NBT chloride substrate (KPL). IgM-secreting B cells were enumerated using Phoretix Expression software (Non-Linear Dynamics).

\section{SINGLE CELL SEQUENCING AND ANALYSIS}

Splenic CD138 ${ }^{+}$B-1a and CD138- B-1a cells were sorted onto 48-well AmpliGrid slides (Advalytix). Reverse transcription and PCR (Qiagen OneStep RT-PCR) were carried out as described previously (8). The products were purified and then sequenced (Genewiz) using the MsVHE primer. Sequences were then analyzed using an online sequence analysis tool for VDJ sequences
(IMGT, the international ImMunoGeneTics information system). Each of the sequences analyzed and reported in this manuscript, from each population, is characterized by a unique $\mathrm{V}, \mathrm{D}$, and $\mathrm{J}$ segment along with a unique CDR3. Sequences with identical V, $\mathrm{D}$, and J segments as well as identical CDR3 regions were eliminated from consideration according to the criteria of Kantor et al. (26). CDR3 hydrophobicity was calculated using the online calculator GRAVY (http://www.gravy-calculator.de/index.php?page= file). Sequences are provided as Data Sheet in Supplementary Material.

\section{RESULTS}

We sort purified splenic B-1a cells to separate $\mathrm{CD}_{138^{+}}$and $\mathrm{CD}_{138^{-}}$populations using a variation on the gating strategy reported by Herzenberg and colleagues (24). The selected splenic populations were gated as $\mathrm{B} 220^{\mathrm{lo}} \mathrm{CD} 5^{\mathrm{lo}} \mathrm{CD} 23^{-} \mathrm{CD} 138^{+}\left(\mathrm{CD} 138^{+}\right.$ $\mathrm{B}-1 \mathrm{a}$ cells) and $\mathrm{B} 220^{\mathrm{lo}} \mathrm{CD} 5^{\mathrm{lo}} \mathrm{CD} 23^{-} \mathrm{CD} 138^{-}$(CD138- $\mathrm{B}-1 \mathrm{a}$ cells $)$, as depicted in Figure 1. Far fewer CD138 ${ }^{+}$B-1a cells were recovered than $\mathrm{CD} 138^{-} \mathrm{B}-1 \mathrm{a}$ cells with the former amounting to less than $1 / 100$ the number of the latter. We questioned whether CD138 expression marks splenic B-1a cells that vigorously secrete Ig, as it does B-2 plasma cells. To address this, we tested IgM secretion of sorted splenic B-1a cells from naïve, unimmunized $\mathrm{BALB} / \mathrm{c}-\mathrm{ByJ}$ mice by ELISPOT assay. We found both $\mathrm{CD} 138^{+}$and CD138- B-1a cells secreted IgM spontaneously, without stimulation, over a $4 \mathrm{~h}$ period. However, the frequency of IgM-secreting $\mathrm{B}$-1a cells was significantly higher for $\mathrm{CD} 138^{+} \mathrm{B}-1 \mathrm{a}$ cells in comparison to $\mathrm{CD} 138^{-}$B-1a cells, as illustrated in Figure $2 \mathrm{~A}$ and enumerated in Figure 2B. More than half of $\mathrm{CD}_{138^{+}}$splenic Bla cells (56\%) spontaneously secreted IgM whereas the fraction of CD138- splenic B- 1 a cells that secreted IgM (5\%) was much lower. Beyond frequency, the amount of IgM secreted by CD $138^{+}$splenic
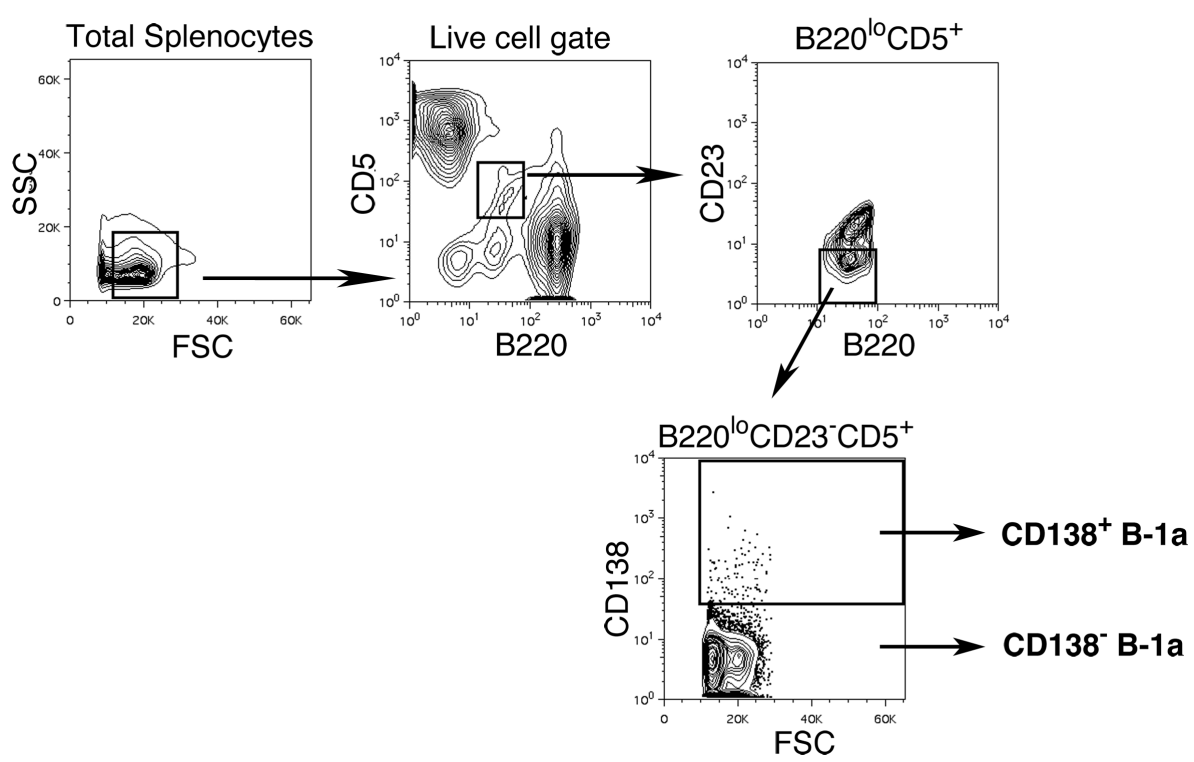

FIGURE 1 | Gating strategy for CD138+ $^{+}$and CD138- splenic B-1a cells in naïve non-immune mice. Single cell suspensions of RBC lysed spleens from BALB/C-ByJ mice were prepared and stained with B220-FITC, CD5-PE-Cy5, CD23-Pacific Blue, and CD138-PE. Splenic CD138+ and CD138- B-1a cells were gated as shown and sorted. 
A

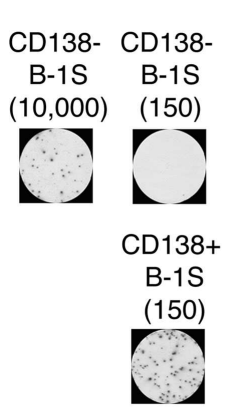

B

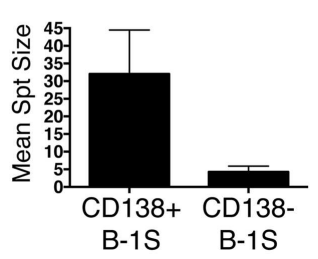

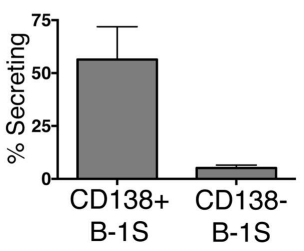

FIGURE 2 | $\mathrm{CD}^{138^{+}}$and $\mathrm{CD} 138^{-}$splenic $\mathrm{B}-1$ a cell IgM secretion in naïve non-immune mice. Sorted splenic $\mathrm{CD}_{138^{+}}$and $\mathrm{CD} 138^{-} \mathrm{B}-1$ a cells were evaluated for IgM secretion by ELISPOT. Cells were placed on the ELISPOT membrane for $4 \mathrm{~h}$. (A) Representative experiment showing 10,000 or 150 CD138- cells total placed per well as compared to 150 CD $138^{+}$cells total per well. (B) The spots were enumerated to determine mean spot area (black) and the percent of cells secreting IgM (gray). Results shown represent mean values of three independent experiments with lines indicating standard errors of the means.

B-1a cells was significantly greater than that of $\mathrm{CD} 138^{-}$splenic Bla cells, as judged by relative mean spot area (Figure 2B). CD $138^{+}$ $\mathrm{B}-1 \mathrm{a}$ cells generated ELISPOTS that were more than six times as large as the ELISPOTS produced by CD138 ${ }^{-}$B-1a cells. Still, both $\mathrm{CD} 138^{+}$and $\mathrm{CD} 138^{-}$splenic B-1a cells secreted more IgM per cell than peritoneal B-1a cells (18).

We questioned whether IgM produced by $\mathrm{CD} 138^{+} \mathrm{B}-1 \mathrm{a}$ cells represents a selected repertoire in comparison to $\mathrm{CD} 138^{-} \mathrm{B}-1 \mathrm{a}$ cells. To address this, we sorted single cell $\mathrm{CD} 138^{+}$and $\mathrm{CD} 138^{-}$ splenic B-1a cells and analyzed individual antibodies by PCR amplification and sequencing. We found overall similarity in $\mathrm{V}_{\mathrm{H}}-\mathrm{D}_{\mathrm{H}}-\mathrm{J}_{\mathrm{H}}$ usage with several significant differences. Among $\mathrm{V}_{\mathrm{H}}$ gene segments, $\mathrm{V}_{\mathrm{H}} 3$ was expressed significantly less frequently by $\mathrm{CD} 138^{+}$splenic B-1a cells $(3 \% ; n=77$; Figure $3 \mathrm{~A})$ as compared to CD138 ${ }^{-}$splenic B-1a cells $(16 \% ; n=92$; Figure $3 \mathrm{~A})$ $(p=0.003) . \mathrm{CD} 138^{+}$splenic B-1a cells also expressed $\mathrm{V}_{\mathrm{H}} 3$ less frequently than peritoneal B-1a cells $[13 \% ; n=56$; Ref. (8)] $(p=0.02)$. In contrast, $\mathrm{V}_{\mathrm{H}} 5$ was expressed more frequently by CD138 ${ }^{+}$splenic B-1a cells $(29 \%)$ as compared to CD $138^{-}$ splenic B-1a cells (20\%), although this difference did not reach the level of significance. Among $\mathrm{D}_{\mathrm{H}}$ gene segments, DFL16.1 was expressed less frequently, and DSP was expressed more frequently, by $\mathrm{CD} 138^{+}$splenic B-1a cells as compared to $\mathrm{CD} 138^{-}$ splenic B-1a cells although these differences were not significant (Figure 3C). Among $\mathrm{J}_{\mathrm{H}}$ gene segments, $\mathrm{J}_{\mathrm{H}} 3$ was expressed significantly more frequently $(42 \%$; Figure $3 \mathbf{B})(p=0.005)$ and $\mathrm{J}_{\mathrm{H}} 2$ was expressed significantly less frequently $(18 \%$; Figure $3 \mathrm{~B})(p=0.03)$, by $\mathrm{CD} 138^{+}$splenic B-1a cells as compared to $\mathrm{CD} 138^{-}$splenic
A

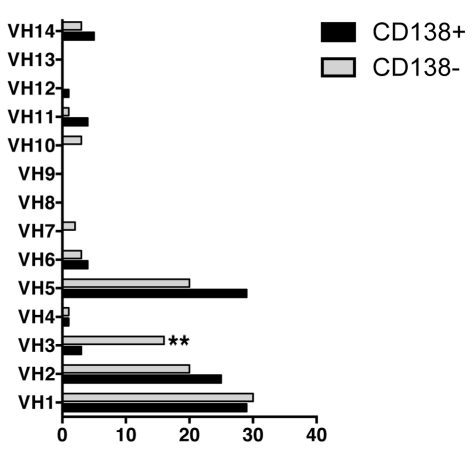

B

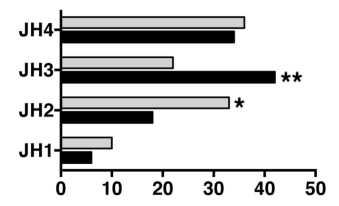

C

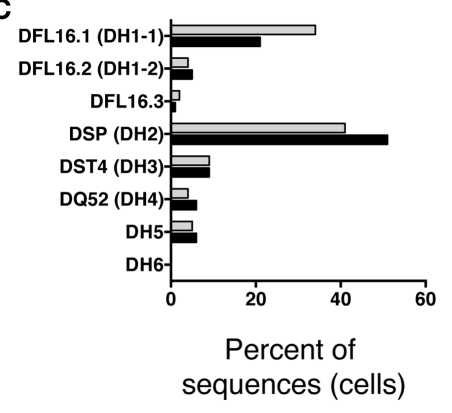

FIGURE 3 | VH, DH, and $\mathrm{JH}$ analysis of $\mathrm{CD}^{138^{+}}$and CD138- splenic B-1a cells. Immunoglobulins were amplified by PCR from single sorted splenic $\mathrm{CD}^{138^{+}}(n=77)$ and CD138- $(n=92) \mathrm{B}-1$ a cells and evaluated for (A) V, (B) $\mathrm{J}$, and (C) D segment heavy chain usage. The percent of cells (sequences) expressing each segment is displayed. Chi square and Fisher's exact tests were used to determine significance.

B-1a cells (22 and 33\%, respectively). The latter utilization of $\mathrm{J}_{\mathrm{H}} 3$ and $\mathrm{J}_{\mathrm{H}} 2$ by $\mathrm{CD} 138^{-}$splenic B-1a cells approximated that of peritoneal B-1a cells [18 and 27\%, respectively, Ref. (8)]. Thus, distinctive $\mathrm{V}$ and $\mathrm{J}$ gene segment usage separated $\mathrm{CD} 138^{+}$splenic B-1a cells from CD138- splenic B-1a cells and peritoneal B-1a cells.

Much attention has focused on N-region addition in B-1a cell Ig, which is typically severely limited in comparison to B-2 cell Ig. We questioned whether $\mathrm{CD} 138^{+} \mathrm{B}-1 \mathrm{a}$ cell Ig represents a selected subset of all B-1a cell Ig. To address this, we analyzed $\mathrm{N}$-addition at the D-J and V-D junctions and determined CDR3 length. Analyzing the junctions separately, we found the average length of $\mathrm{N}$-additions at the $\mathrm{D}-\mathrm{J}$ junction of $\mathrm{CD} 138^{+}$splenic B1a cell antibodies was larger than that of $\mathrm{CD} 138^{-}$splenic B-1a cells $(p=0.03$ by Mann-Whitney $U$ ) (Table 1 ). This bespeaks increased diversity among antibodies expressed by $\mathrm{CD} 138^{+} \mathrm{B}-$ 1a cells as compared to CD138- B-1a cells. However, there were no significant differences between $\mathrm{CD} 138^{+}$and $\mathrm{CD} 138^{-}$splenic B-1 cell antibodies at $\mathrm{V}-\mathrm{D}$ junction in terms of mean $\mathrm{N}$-addition 
length. Regardless, overall N-addition in $\mathrm{CD} 138^{+}$splenic B-1a cell Ig was significantly different ( $p=0.003$ by Chi square analysis) from that of $\mathrm{CD}_{138^{-}}$splenic B-1a cell Ig (Figure 4B), emphasizing that CD138 expression divides splenic B-1a cells into distinct populations.

In previous work, we analyzed $\mathrm{N}$-addition frequency of Ig sequences amplified from peritoneal B-1a cells and from splenic B-2 cells (8). Antibodies expressed by both CD138 ${ }^{+}$ and $\mathrm{CD}_{138^{-}}$splenic B-1a cells contained significantly more $\mathrm{N}$ additions (Figure 4A) in comparison to antibodies expressed by

Table 1 | Mean N-region addition and CDR3 lengths ( \pm SD).

\begin{tabular}{cccc}
\hline & V-D & D-J & CDR3 length \\
\hline CD138 $^{+}$splenic B-1a & $1.7( \pm 2.2)$ & $1.8( \pm 1.9)$ & $11.8( \pm 1.9)$ \\
CD138 $^{-}$splenic B-1a & $2.3( \pm 2.8)$ & $1.3( \pm 1.8)$ & $11.6( \pm 2.6)$
\end{tabular}

B-1a cells in the peritoneal cavity, by Chi square analysis (Figure 4B and Ref. (8); $p<0.0001$ and $p=0.02$, respectively). Conversely, antibodies expressed by both $\mathrm{CD} 138^{+}$and $\mathrm{CD} 138^{-}$splenic B-1a cells contained significantly fewer $\mathrm{N}$-additions in comparison to antibodies expressed by splenic B-2 cells, by Chi square analysis (Figure 4B and Ref. (8); $p=0.0003$ and $p<0.0001$, respectively). Thus, whereas Ig sequences from $\mathrm{CD} 138^{+}$and $\mathrm{CD} 138^{-}$splenic $\mathrm{B}$-1a cells differ in $\mathrm{N}$-addition, both populations of splenic B-1a cells differ from peritoneal B-1a cells and splenic B-2 cells, whose Ig contains less and more $\mathrm{N}$-addition, respectively.

We further examined CDR3 length and found that despite differences in $\mathrm{N}$-addition between $\mathrm{CD} 138^{+}$and $\mathrm{CD} 138^{-}$splenic B-1a cells, average Ig CDR3 lengths were not significantly different for the two populations (Table 1; Figure 4C). Moreover, average Ig CDR3 hydrophobicity indices were similar for CD138 ${ }^{+}$ and $\mathrm{CD} 138^{-}$splenic B-1a cell antibodies $(-0.63 \pm 0.065$ and $-0.69 \pm 0.064$ SEM, respectively). Thus, the small CD $138^{+}$splenic

\section{A}
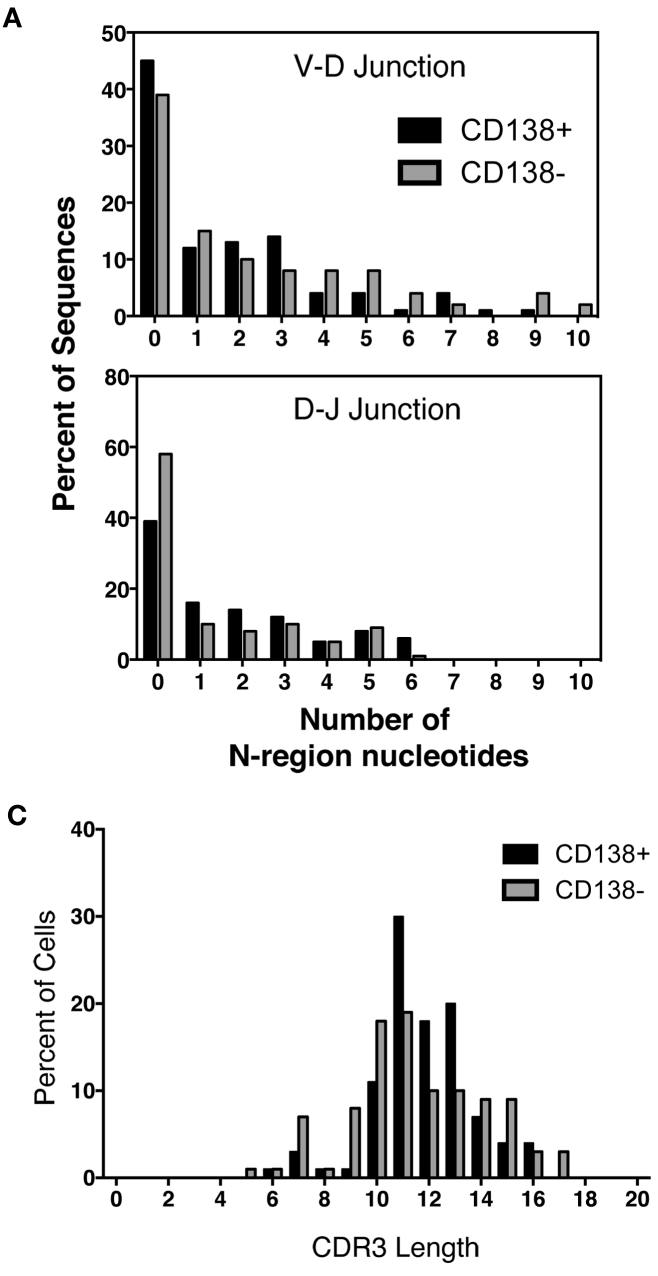

B

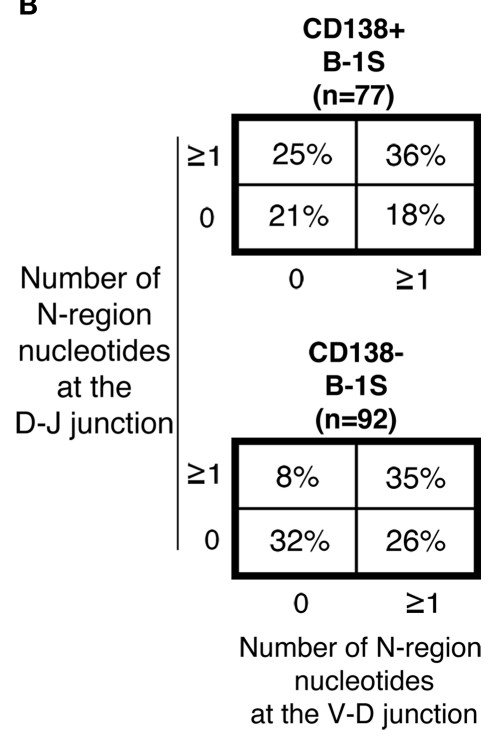

FIGURE 4 | N-region addition and CDR3 length analysis of $\mathrm{CD}_{138}^{+}$and CD138- splenic B-1a cells. Immunoglobulins were amplified by PCR from single sorted splenic $\mathrm{CD}_{138^{+}}(n=77)$ and $\mathrm{CD}_{138^{-}}(n=92) \mathrm{B}-1 \mathrm{a}$ cells and evaluated for $\mathrm{N}$-region additions and CDR3 lengths. (A) The number of $\mathrm{N}$-additions at each junction is shown. The graphs display the percent of sequences with 0-10 N-additions at each junction for $\mathrm{CD} 138^{+}$(black bars) and CD138- (gray bars) splenic B-1a cells. (B) N-addition analysis of the $\mathrm{V}-\mathrm{D}$ and $\mathrm{D}-\mathrm{J}$ junctions together. (C) CDR3 length analysis of immunoglobulin sequences from CD138+ (black bars) and CD138- (gray bars) splenic B-1a cells. 
B-1a cell population expresses Ig that varies in Ig gene segment usage and is more diverse on account of increased $\mathrm{N}$-addition, as compared to the dominant $\mathrm{CD} 138^{-}$splenic B-1a cell population, but differs little in CDR3 length and CDR3 hydrophobicity.

\section{DISCUSSION}

Our results further characterize CD138-bearing B-1a cells, first identified by Yang et al. (24), which appear as a very small B cell population in the spleen. A large fraction of this small population secretes IgM, and an increased amount of $\operatorname{IgM}$ is secreted, in comparison with $\mathrm{CD}_{138^{-}}$splenic B-1a cells and peritoneal B-1a cells. Thus, although their numbers may be small, it is likely that $\mathrm{CD}_{138^{+}}$splenic B-1a cells make a substantial contribution to the circulating pool of natural antibodies. Therefore, the nature of the $\mathrm{CD}_{138^{+}}$antibody repertoire is of interest in understanding the protective capacity of natural IgM.

The repertoire of these potently secreting $\mathrm{CD}_{138^{+}}$splenic B1a cells is somewhat skewed away from $\mathrm{V}_{\mathrm{H}} 3$ and $\mathrm{J}_{\mathrm{H}} 2$, and toward $\mathrm{J}_{\mathrm{H}} 3$. This would seem to parallel the situation with the peritoneal $\mathrm{B}-1 \mathrm{a}$ cell repertoire, in which overall usage of $\mathrm{V}_{\mathrm{H}}$ gene segments is similar to that of B-2 cells except for the key difference of increased $\mathrm{V}_{\mathrm{H}} 11$ and $\mathrm{V}_{\mathrm{H}} 12$ expression, the two $\mathrm{V}_{\mathrm{H}}$ families responsible for PtC binding (27-29). In other words, repertoire skewing can show up in a limited way, which may be the case here with the preferential use of a very small number of $\mathrm{V}_{\mathrm{H}}$ and $\mathrm{J}_{\mathrm{H}}$ gene segments by $\mathrm{CD}_{138^{+}}$splenic B-1a cells.

Prominent among variably expressed $\mathrm{V}_{\mathrm{H}}$ gene segments is $\mathrm{V}_{\mathrm{H}} 3$, which was found to be increased in NZM2410 anti-nuclear antibodies as compared to antibodies that did not bind nuclear components (30). This might suggest that $\mathrm{CD} 138^{+}$splenic B-1a cells predominantly generate anti-microbial as opposed to self-reactive antibodies; however, in NZM2410 mice $\mathrm{V}_{\mathrm{H}} 5$ is also increased in anti-nuclear antibodies (30) and among splenic B-1a cells $\mathrm{V}_{\mathrm{H}} 5$ is utilized more frequently by $\mathrm{CD}_{138^{+}} \mathrm{B}-1$ a cells as compared to CD138- B-1a cells, although this difference did not reach statistical significance. Thus, there is no clear evidence that $\mathrm{CD} 138^{+} \mathrm{B}-1 \mathrm{a}$ cell Ig skews more toward or away from autoreactivity.

Both $\mathrm{CD}_{138^{+}}$and $\mathrm{CD} 138^{-}$splenic B-1a cell Ig sequences contained more $\mathrm{N}$-addition than peritoneal B-1a cells' Ig sequences (and less $\mathrm{N}$-addition than splenic B-2 cell Ig sequences), suggesting that the splenic B-1a pool differs from B-1a cells located elsewhere as well as from B-2 cells that share the splenic environment. Moreover, among splenic B-1a cell Ig, CD138 ${ }^{+}$B-1a sequences contained more $\mathrm{N}$-addition than $\mathrm{CD} 138^{-}$sequences. It has been shown the natural IgM produced by B-1a cells is essential for early protection against bacterial and viral infections and that $\mathrm{N}$ addition plays a substantial role in determining antibody diversity and effectiveness $(10,11,13,15)$. For example, the prototypical B-1a anti-phosphorylcholine (PC) antibody, T15, represents a germline sequence and has no $\mathrm{N}$-addition (31). T15 has been shown to be protective against Streptococcus pneumoniae infection (31). The relationship between $\mathrm{N}$-addition and antibody function is illustrated by the finding that after vaccination with heat killed pneumococci, mice that overexpress TdT generated an antiPC response, but the anti-PC antibodies in this situation were not protective against $S$. pneumoniae infection (32). These findings highlight the importance of $\mathrm{N}$-addition, which varies among antibodies spontaneously secreted by $\mathrm{CD} 138^{+}$splenic B-1a cells, CD138- B-1a splenic B-1a cells, and peritoneal B-1a cells, in determining protection by natural antibody.

Circulating natural antibody is primarily generated by splenic B-1a cells, which differ in many characteristics from peritoneal B-1a cells (17-19). Among splenic B-1a cells, CD138+ ${ }^{+}$- 1 a cells differ from CD138 ${ }^{-}$B-1a cells in the frequency of secreting cells, the amount of antibody secreted, and the repertoire of antibody expressed. The combination of skewing with respect to $\mathrm{V}_{\mathrm{H}}$ and $\mathrm{J}_{\mathrm{H}}$ gene segments, and degree of N-region addition, suggests that the $\mathrm{CD} 138^{+} \mathrm{B}-1 \mathrm{a}$ cell pool does not result from randomly triggered differentiation events applied to all splenic B-1a cells or all peritoneal B-1a cells, but rather results from a selective process whose origin remains unclear.

This raises the question of how the distinct splenic B-1a populations come about, and whether this represents selection from a pre-existing population or contribution from a new or different source. Previous work suggests several potential mechanisms. Peritoneal B-1a cells may migrate to the spleen following antigenspecific (or non-specific) activation (21-23, 33, 34). Herzenberg and colleagues have shown that these B-1a cells may become antibody secreting cells and/or return to the peritoneal cavity as memory B cells $(21-23,33,34)$. In addition, we and others have suggested that the pool of B-1a cells changes with age, as fetal liverderived B-1a cells are slowly replaced by bone marrow-derived $\mathrm{B}-1 \mathrm{a}$ cells in the adult expressing antibody with increased levels of $\mathrm{N}$-addition $(8,35,36)$, and the latter could preferentially give rise to splenic B-1a cells. A further possibility relates to the report of B1 progenitor cells in the spleen that might give rise to mature $B-1 \mathrm{a}$ cells in situ $(37,38)$. In fact, a combination of these mechanisms may be at play, whereby the fetal liver B-1a pool in the peritoneal cavity is replaced by bone marrow-derived B-1a emigrants over time, which then become activated and migrate to the spleen in a selective fashion. It will be of interest to determine whether the $\mathrm{N}$-addition and other characteristics of $\mathrm{CD} 138^{+} \mathrm{B}$-1a cells change with advancing age. In sum, $\mathrm{CD} 138^{+}$splenic B-1a cells constitute a distinct B-1a cell population that appears to play a substantial role in generation of natural antibody.

\section{SUPPLEMENTARY MATERIAL}

The Supplementary Material for this article can be found online at http://www.frontiersin.org/Journal/10.3389/fimmu.2014.00129/ abstract.

\section{REFERENCES}

1. Herzenberg LA, Tung JW. B cell lineages: documented at last! Nat Immunol (2006) 7:225-6. doi:10.1038/ni0306-225

2. Rothstein TL, Griffin DO, Holodick NE, Quach TD, Kaku H. Human B-1 cells take the stage. Ann N Y Acad Sci (2013) 1285:97-114. doi:10.1111/nyas.12137

3. Griffin DO, Holodick NE, Rothstein TL. Human B1 cells in umbilical cord and adult peripheral blood express the novel phenotype CD20+CD27+CD43+CD70. J Exp Med (2011) 208:67-80. doi:10.1084/jem. 20101499

4. Griffin DO, Rothstein TL. Human B1 cell frequency: isolation and analysis of human B1 cells. Front Immunol (2012) 3:122. doi:10.3389/fimmu.2012.00122

5. Herzenberg LA. B-1 cells: the lineage question revisited. Immunol Rev (2000) 175:9-22. doi:10.1111/j.1600-065X.2000.imr017520.x

6. Feeney AJ. Lack of $\mathrm{N}$ regions in fetal and neonatal mouse immunoglobulin VD-J junctional sequences. J Exp Med (1990) 172:1377-90. doi:10.1084/jem.172. 5.1377 
7. Forster I, Rajewsky K. Expansion and functional activity of Ly-1+ B cells upon transfer of peritoneal cells into allotype-congenic, newborn mice. Eur J Immunol (1987) 17:521-8. doi:10.1002/eji.1830170414

8. Holodick NE, Repetny K, Zhong X, Rothstein TL. Adult BM generates CD5+ B1 cells containing abundant N-region additions. Eur J Immunol (2009) 39:2383-94. doi:10.1002/eji.200838920

9. Sidman CL, Shultz LD, Hardy RR, Hayakawa K, Herzenberg LA. Production of immunoglobulin isotypes by Ly-1+ B cells in viable motheaten and normal mice. Science (1986) 232:1423-5. doi:10.1126/science.3487115

10. Baumgarth N, Herman OC, Jager GC, Brown LE, Herzenberg LA, Chen J. B-1 and B-2 cell-derived immunoglobulin $\mathrm{M}$ antibodies are nonredundant components of the protective response to influenza virus infection. J Exp Med (2000) 192:271-80. doi:10.1084/jem.192.2.271

11. Haas KM, Poe JC, Steeber DA, Tedder TF. B-1a and B-1b cells exhibit distinct developmental requirements and have unique functional roles in innate and adaptive immunity to S. pneumoniae. Immunity (2005) 23:7-18. doi:10.1016/j. immuni.2005.04.011

12. Hardy RR, Hayakawa K. B cell development pathways. Annu Rev Immunol (2001) 19:595-621. doi:10.1146/annurev.immunol.19.1.595

13. Ochsenbein AF, Fehr T, Lutz C, Suter M, Brombacher F, Hengartner H, et al. Control of early viral and bacterial distribution and disease by natural antibodies. Science (1999) 286:2156-9. doi:10.1126/science.286.5447.2156

14. Rothstein TL. Cutting edge commentary: two B-1 or not to be one. J Immunol (2002) 168:4257-61.

15. Su SD, Ward MM, Apicella MA, Ward RE. The primary B cell response to the $\mathrm{O} /$ core region of bacterial lipopolysaccharide is restricted to the Ly-1 lineage. J Immunol (1991) 146:327-31.

16. Gronwall C, Vas J, Silverman GJ. Protective roles of natural IgM antibodies. Front Immunol (2012) 3:66. doi:10.3389/fimmu.2012.00066

17. Fischer GM, Solt LA, Hastings WD, Yang K, Gerstein RM, Nikolajczyk BS, et al. Splenic and peritoneal B-1 cells differ in terms of transcriptional and proliferative features that separate peritoneal B-1 from splenic B-2 cells. Cell Immunol (2001) 213:62-71. doi:10.1006/cimm.2001.1860

18. Holodick NE, Tumang JR, Rothstein TL. B1 cells constitutively secrete IgM independently of IRF4. Eur J Immunol (2010) 40:3007-16. doi:10.1002/eji. 201040545

19. Tumang JR, Hastings WD, Bai C, Rothstein TL. Peritoneal and splenic B-1 cells are separable by phenotypic, functional, and transcriptomic characteristics. Eur J Immunol (2004) 34:2158-67. doi:10.1002/eji.200424819

20. Hayakawa K, Hardy RR, Stall AM, Herzenberg LA. Immunoglobulin-bearing B cells reconstitute and maintain the murine Ly-1 B cell lineage. Eur J Immunol (1986) 16:1313-6. doi:10.1002/eji.1830161021

21. Ha SA, Tsuji M, Suzuki K, Meek B, Yasuda N, Kaisho T, et al. Regulation of B1 cell migration by signals through toll-like receptors. J Exp Med (2006) 203:2541-50. doi:10.1084/jem.20061041

22. Yang Y, Ghosn EE, Cole LE, Obukhanych TV, Sadate-Ngatchou P, Vogel SN, et al. Antigen-specific antibody responses in B-1a and their relationship to natural immunity. Proc Natl Acad Sci U S A (2012) 109:5382-7. doi:10.1073/pnas. 1121631109

23. Yang Y, Ghosn EE, Cole LE, Obukhanych TV, Sadate-Ngatchou P, Vogel SN, et al. Antigen-specific memory in B-1a and its relationship to natural immunity. Proc Natl Acad Sci U S A (2012) 109:5388-93. doi:10.1073/pnas.1121627109

24. Yang Y, Tung JW, Ghosn EE, Herzenberg LA, Herzenberg LA. Division and differentiation of natural antibody-producing cells in mouse spleen. Proc Natl Acad Sci U S A (2007) 104:4542-6. doi:10.1073/pnas.0700001104

25. Tumang JR, Frances R, Yeo SG, Rothstein TL. Cutting edge: spontaneously Ig-secreting B-1 cells violate the accepted paradigm for expression of differentiation-associated transcription factors. J Immunol (2005) 174:3173-7.
26. Kantor AB, Merrill CE, Herzenberg LA, Hillson JL. An unbiased analysis of $\mathrm{V}(\mathrm{H})-\mathrm{D}-\mathrm{J}(\mathrm{H})$ sequences from B-1a, B-1b, and conventional B cells. J Immunol (1997) 158:1175-86.

27. Hardy RR, Carmack CE, Shinton SA, Riblet RJ, Hayakawa K. A single VH gene is utilized predominantly in anti-BrMRBC hybridomas derived from purified Ly-1 B cells. Definition of the VH11 family. J Immunol (1989) 142:3643-51.

28. Mercolino TJ, Locke AL, Afshari A, Sasser D, Travis WW, Arnold LW, et al. Restricted immunoglobulin variable region gene usage by normal Ly-1 (CD5+) B cells that recognize phosphatidyl choline. J Exp Med (1989) 169:1869-77. doi:10.1084/jem.169.6.1869

29. Pennell CA, Mercolino TJ, Grdina TA, Arnold LW, Haughton G, Clarke SH. Biased immunoglobulin variable region gene expression by Ly-1 B cells due to clonal selection. Eur J Immunol (1989) 19:1289-95. doi:10.1002/eji.1830190721

30. Liang Z, Xie C, Chen C, Kreska D, Hsu K, Li L, et al. Pathogenic profiles and molecular signatures of antinuclear autoantibodies rescued from NZM2410 lupus mice. J Exp Med (2004) 199:381-98. doi:10.1084/jem.20030132

31. Briles DE, Forman C, Hudak S, Claflin JL. Anti-phosphorylcholine antibodies of the T15 idiotype are optimally protective against Streptococcus pneumoniae. J Exp Med (1982) 156:1177-85. doi:10.1084/jem.156.4.1177

32. Benedict CL, Kearney JF. Increased junctional diversity in fetal B cells results in a loss of protective anti-phosphorylcholine antibodies in adult mice. Immunity (1999) 10:607-17. doi:10.1016/S1074-7613(00)80060-6

33. Itakura A, Szczepanik M, Campos RA, Paliwal V, Majewska M, Matsuda H, et al. An hour after immunization peritoneal B-1 cells are activated to migrate to lymphoid organs where within 1 day they produce $\operatorname{IgM}$ antibodies that initiate elicitation of contact sensitivity. J Immunol (2005) 175:7170-8.

34. Kawahara T, Ohdan H, Zhao G, Yang YG, Sykes MM. Peritoneal cavity B cells are precursors of splenic IgM natural antibody-producing cells. J Immunol (2003) 171:5406-14.

35. Duber S, Hafner M, Krey M, Lienenklaus S, Roy B, Hobeika E, et al. Induction of B-cell development in adult mice reveals the ability of bone marrow to produce B-1a cells. Blood (2009) 114:4960-7. doi:10.1182/blood-2009-04-218156

36. Esplin BL, Welner RS, Zhang Q, Borghesi LA, Kincade PW. A differentiation pathway for B1 cells in adult bone marrow. Proc Natl Acad Sci U S A (2009) 106:5773-8. doi:10.1073/pnas.0811632106

37. Ghosn EE, Sadate-Ngatchou P, Yang Y, Herzenberg LA. Distinct progenitors for B-1 and B-2 cells are present in adult mouse spleen. Proc Natl Acad Sci U S A (2011) 108:2879-84. doi:10.1073/pnas.1019764108

38. Wardemann H, Boehm T, Dear N, Carsetti R. B-1a B cells that link the innate and adaptive immune responses are lacking in the absence of the spleen. J Exp Med (2002) 195:771-80. doi:10.1084/jem.20011140

Conflict of Interest Statement: The authors declare that the research was conducted in the absence of any commercial or financial relationships that could be construed as a potential conflict of interest.

Received: 17 January 2014; accepted: 14 March 2014; published online: 28 March 2014. Citation: Holodick NE, Vizconde T and Rothstein TL (2014) Splenic B-1 a cells expressing CD138 spontaneously secrete large amounts of immunoglobulin in naïve mice. Front. Immunol. 5:129. doi: 10.3389/fimmu.2014.00129

This article was submitted to B Cell Biology, a section of the journal Frontiers in Immunology.

Copyright (C) 2014 Holodick, Vizconde and Rothstein. This is an open-access article distributed under the terms of the Creative Commons Attribution License (CC BY). The use, distribution or reproduction in other forums is permitted, provided the original author(s) or licensor are credited and that the original publication in this journal is cited, in accordance with accepted academic practice. No use, distribution or reproduction is permitted which does not comply with these terms. 